\title{
PENGEMBANGAN KIT TAKE-HOME EXPERIMENT CAHAYA DAN OPTIK SEBAGAI MEDIA PEMBELAJARAN SAINS SISWA SLTP
}

\author{
Zulirfan $^{1,2)}$, Zanaton Haji Iksan ${ }^{2)}$, Tamby Subahan Mohd. Meerah ${ }^{2)}$ \\ ${ }^{1)}$ Program Studi Pendidikan Fisika FKIP, Universitas Riau \\ ${ }^{2)}$ Fakulti Pendidikan, Universiti Kebangsaan Malaysia \\ e-mail: zirfanaziz69@gmail.com
}

\begin{abstract}
Abstrak
Kit take home experiment ini dikembangkan untuk membantu para siswa SLTP dalam membangun keterampilan saintifik dan sikap saintifik mereka. Keterampilan saintifik dan sikap saintifik ini hanya dapat dilatihkan kepada siswa melalui kegiatan yang memberikan pengalaman langsung yang dalam hal ini adalah pengamatan dan eksperimen. Menggunakan kit eksperimen sains sederhana yang dikembangkan dalam penelitian ini, diharapkan siswa dapat melakukan pengamatan dan eksperimen sains di rumah mereka masing-masing kapanpun mereka mau dan tidak perlu dibatasi oleh dinding-dinding laboratorium. Langkahlangkah eksperimen yang telah mereka jalankan dan hasil eksperimen yang mereka dapatkan selanjutnya akan didiskusikan di dalam kelas di bawah bimbingan guru. Tujuan penelitian ini adalah untuk mengembangkan kit cahaya dan optik yang dapat digunakan siswa untu berkesperimen di rumah. Pengembangan kit THE ini menggunakan sistem pengembangan desains instruksional model ADDIE yang meliputi: analysis, design, development, implementation, dan evaluation. Kit take home experiment ini telah melalui tahapan penilaian pakar dan uji coba kepraktisan.
\end{abstract}

Kata Kunci: cahaya dan optik, kit take home experiment, keterampilan saintifik, sikap saintifik

\begin{abstract}
A take home experiment kit has been developed to help junior high school students increase their scientific skills and scientific attitudes. Scientific skills and scientific attitudes of students can only be developed through hands on activity, in this case is through observing science objects or phenomena and conducting an experiment. By using this simple experiment kit, students are expected to be able to conduct their home experiments whenever and wherever. What they have done in their experiments and their findings will be discussed in classroom with their science teachers. The purpose of this study was to develop light and optical kits that can be used by students for conducting science experiment at home. The development of this take home experiment kit used ADDIE's model, one of the instructional design systems. The steps include analysis, design, development, implementation, and evaluation. This take home experiment kit has gone through the stages of expert judgment and practicality testing.
\end{abstract}

Keywords: light and optics, scientific attitudes, scientific skills, take home experiment kit 


\section{Pendahuluan}

Kurikulum 2013 maupun kurikulum 2006, mengamanatkan bahwa pembelajaran sains haruslah menggunakan pendekatan saintifik melalui aktivitas: mengamati, menanya, mencoba, mengolah data, menyaji kan, menyimpulkan, dan mencipta dalam usaha memahami fenomena alam semesta dan memanfaatkan pengetahuan sains untuk kesejahteraan umat manusia. Proses pembelajaran berbasis pendekatan saintifik ini bertujuan untuk menguatkan pembelajaran aktif yakni dari siswa 'diberitahu' menjadi siswa 'mencari tahu' (Kemdikbud 2013; Sudarwan, 2013). Hal ini dituangkan dalam Peraturan Menteri Pendidikan dan Kebudayaan Republik Indone sia, nomor 81a tahun 2013 yang menyatakan bahwa proses pembelajaran terdiri atas lima pengalaman belajar pokok yaitu: mengamati (observe), menanya (questioning), mengumpulkan data (collect data), mengolah data (ascociate), dan mengkomunikasikan (com municate).

Dalam pembelajaran sains, aktivitas saintifik ini dikembangkan menjadi aktivitas saintifik yang lebih lengkap yang dikenal sebagai metode ilmiah. Untuk menerapkan metode ilmiah dalam pembelajaran sains, metode pembelajaran yang paling sesuai adalah eksperimen atau kerja praktikum. Selain itu, metode eksperimen juga dapat memperkuat pemahaman konsep yang dipe roleh berdasarkan hasil eksperimen. Hal ini sesuai dengan pendapat Ottander dan Grelsson (2006) yang mengatakan bahwa aktivitas praktikum dalam pendidikan sains bertujuan membantu para siswa memperoleh pemahaman konsep dan membangun pemahaman tentang sifat dan metode ilmiah.

Pembelajaran sains melalui kegiatan pengamatan atau eksperimen akan melatih kemampuan saintifik siswa. Kemampuan saintifik dalam hal ini adalah keterampilan proses sains dan keterampilan manipulatif. Kemampuan ini sangat menentukan keber hasilan suatu penyelidikan ilmiah. Yoon dan Kim (2010) menyatakan bahwa salah satu hal yang penting untuk mengarahkan siswa memperoleh keterampilan proses sains adalah melalui kerja praktikum. Kerja praktikum memperbolehkan siswa melakukan kerja ilmiah secara langsung sehingga pengetahuan sains diturunkan secara langsung melalui kegiatan-kegiatan ilmiah tersebut.

Keterampilan proses sains (KPS) meru pakan keterampilan dasar dalam menjalankan suatu penyelidikan (Ergul, 2011; Bilgin, 2006; Nuryani Rustaman, 2013). Disamping keterampilan proses sains (KPS), menerapkan metode ilmiah dalam pembelajaran sains juga memerlukan kekuatan mental yang diwujud kan dalam sikap saintifik (scientific attitudes). Kaur (2013) menyatakan bahwa sikap saintifik (SS) merupakan 'semangat saintifik (scientific spirit)' yang akan menghasilkan suatu pandangan yang rasional dan sikap saintifik membantu memecahkan masalah secara objektif tanpa bias dengan mengedepankan pikiran logis.

Pada kenyataannya, pembelajaran sains pada umumnya dilakukan dengan metode ceramah. Banyak kajian yang menunjukkan bahwa pembelajaran sains hanya mengedepan kan tercapainya hasil belajar koginitif semata melalui pembelajaran yang jauh dari pende katan saintifik tersebut. Sebagian besar siswa hanya duduk dan menghafal fakta-fakta sains dan konsep-konsep dari buku teks sains mereka sambil bertanya dalam hati apa perlunya mereka mempelajari semua ini (Mallya, et al. 2012). Sementara itu Suyana (2011) menyatakan bahwa pembelajaran sains terutama fisika pada umumnya dilakukan melalui ceramah dan siswa cenderung menghafal banyak istilah yang berhubungan dengan fisika dan konsep fisika sehingga pengetahuan fisika mereka bersifat verbalistik dan tidak bermakna.

Banyak faktor yang menjadi penghambat pelaksanaan metode eksperimen dalam pembelajaran sains tersebut. Beberapa kajian terdahulu menunjukkan bahwa hambatan pelaksanaan metode eksperimen diantaranya: tidak tersedia ruang laboratorium untuk kegiatan ekperimen, laboratorium dipakai bersama oleh banyak kelas, tidak ada atau kurangnya alat dan bahan eksperimen, dan pelaksanaan metode eksperimen memakan waktu yang lama (Sumintono, 2011; Thair \& Treagust, 1999; Hazrulrizawati, 2007; Yennita, 2012). Dari pengamatan di lapangan, ternyata di sekolah-sekolah yang mempunyai laborato rium dengan peralatan eksperimen yang memadaipun, metode eksperimen jarang dilakukan. 
Berdasarkan hasil kajian Zulirfan (2013), alasan utama para guru terhadap persoalan ini adalah waktu yang tersedia dalam jam pelajaran sains di sekolah tidak mencukupi untuk menerapkan metode eksperimen, sedangkan konten atau pengeta huan sains yang harus diajarkan cukup padat. Hal ini diperkuat oleh Norlander-Case, (1998) yang mengungkapkan bahwa satu tantangan dalam menerapkan pembelajaran berbasis inkuiri adalah kekurangan waktu.

Zulirfan (2013) telah mengajukan satu alternatif solusi untuk mengatasi permasala han yang telah diungkapkan di atas yang dengan membangun suatu strategi yang dikenal sebagai strategi take-home experiments (THE). Melalui strategi ini, siswa dapat melaksanakan pengamatan dan atau eksperimen di rumah mereka masing-masing kapanpun mereka mau dan dimanapun di setiap sudut di rumah atau di pekarangan rumah. Menjalankan eksperimen sains tidak dibatasi oleh ruang-ruang laboratorium dengan perangkat pendukungnya, kecuali untuk sebagian kecil topik eksperimen tertentu.

Untuk mendukung strategi take-home experiment ini, diperlukan perangkat pembela jaran seperti: kit eksperimen, modul pembela jaran untuk siswa atau LKS, dan modul pengajaran untuk guru. Perangkat ini digunakan siswa untuk menjalankan ekspe rimen di rumah dan menjelaskan hasilnya di sekolah yang difasilitasi oleh guru. Agar strategi ini dapat terlaksana dengan baik, maka perangkat pembelajaran haruslah valid dan praktis untuk digunakan. Oleh karena itu, pengembangan kit take home experiment, modul siswa dan modul guru haruslah melalui sebuah proses riset pengembangan.

Dalam kajian ini, peneliti memfokuskan pada pengembangan kit take home experiment (kit THE) pada topik cahaya dan optik. Pemilihan topik cahaya dan optik didasari bahwa konsep cahaya dan optik ditemukan siswa melalui pengamatan dan eksperimen, sesuai dengan kompetensi dasar terkait dengan KD 3.11 dalam Kurikulum 2013 yakni mendeskripsikan sifat-sifat cahaya, pemben tukan bayangan, serta aplikasinya untuk menjelaskan penglihatan manusia, proses pembentukan bayangan pada mata dan prinsip kerja alat optik dan KD 4.11 yaitu membuat laporan hasil penyelidikan tentang pembentukan bayangan pada cermin, lensa dan alat optik.

Alasan lain peneliti memilih topik ini adalah alat dan bahan eksperimen dapat di desain berukuran relatif kecil sehingga dapat dikemas dalam kit yang mudah dibawa pulang oleh siswa. Alat dan bahan eksperimen cahaya dan optik relatif aman untuk digunakan siswa di rumah. Disamping itu, terdapat benda-benda lain di rumah yang dapat digunakan untuk eksperimen cahaya dan optik. Eksperimen cahaya dan optik bersifat kontekstual dan dipandang menarik bagi siswa.

Pengembangan kit THE dalam penelitian ini mengikuti langkah-langkah dalam sistem desain instruksional model ADDIE. Peneliti memilih model ini karena lebih praktis untuk diikuti. Magliaro dan Shambaugh (2006) dan Mc-Gurr (2008) menyatakan bahwa ADDIE merupakan proses yang telah digunakan secara luas dalam pengembangan desain instruksional. Sementara itu Kallio (2008) menyatakan bahwa model ADDIE digunakan dalam kajian semua bentuk pengembangan rancangan instruksional. Terdapat lima langkah penerapan model ADDIE yaitu: Analysis (analisis), Design (perancangan), Develop ment (pem bangunan), Implementa tion (pelaksanaan), dan Evaluation (penilaian).

Secara umum penelitian ini bertujuan untuk menghasilkan kit take-home experiment cahaya dan optik yang dapat digunakan siswa dalam melakukan pengamatan dan atau eksperimen sains secara mandiri di rumah. Secara khusus tujuan penelitian ini adalah untuk:

1. Mengidentifikasi topik atau muatan eksperimen pada materi cahaya dan optik

2. Mengidentifikasi eksperimen apa saja yang memungkinkan dilakukan siswa di rumah secara mandiri.

3. Memilih alat dan bahan yang sesuai digunakan sebagai kit take-home experi ment cahaya dan optik.

4. Merancang ukuran komponen kit dan kotak kit take home experiment yang sesuai.

5. Merakit dan membuat komponen kit takehome experiment

6. Menguji validitas kit take home experiment untuk cahaya dan optik.

7. Menguji praktikalitas kit take home experiment 
Penelitian ini diharapkan dapat memberikan kontribusi antara lain membantu siswa dalam mengembangkan keterampilan proses sains dan sikap saintifik, membantu siswa dalam mengembangkan kemandirian dalam menjalankan suatu penyelidikan ilmiah, membantu guru dalam mengatasi kesulitan melaksanakan eksperimen di sekolah yang disebabkan oleh terbatasnya waktu, kekurangan peralatan, tidak tersedianya labora torium, dan padatnya materi pelajaran. Hasil penelitian ini juga diharapkan dapat membantu guru dalam mengembangkan keterampilan proses sains dan sikap saintifik siswa dan membantu guru dalam mengimplementasikan pendekatan saintifik sesuai tuntutan Kurikulum 2013.

\section{Bahan dan Metode}

Penelitian pengembangan ini mengguna kan model pengembangan disain instruksional ADDIE. Data dalam penelitian ini adalah data tentang penilaian pakar terhadap kesesuaian kit take-home experiment untuk mencapai tujuan penyelidikan atau pengamatan tentang fenomena cahaya dan optik dan data tentang praktikalitas atau kemudahan penggunaan kit oleh siswa di lapangan.

Kit take-home experiment (THE) untuk cahaya dan optik ini baru dinyatakan valid apabila semua komponennya dinilai sangat sesuai atau sesuai. Komponen yang belum valid memerlukan revisi sesuai dengan saransaran pakar (validator) yang dalam hal ini terdiri dari 3 orang yaitu: satu orang guru sains/fisika SLTP senior dengan pendidikan minimal S2 pendidikan sains/fisika, masa kerja lebih dari 15 tahun dan dua orang dosen pendidikan sains dengan kualifikasi akademik S3 bidang pendidikan sains dan berpengalaman lebih dari 15 tahun. Aspek dan indikator penilaian kit take home experiment ditunjuk kan pada Tabel 1.

Tabel 1 menunjukkan bahwa terdapat 5 aspek penilaian oleh pakar yaitu aspek yang berkaitan dengan unsur teori pembelajaran, dimensi hasil belajar, tampilan fisik, dan unsur kepraktisan.

Tabel 1 Aspek dan Indikator Penilaian Kit THE

\begin{tabular}{ll}
\hline \multicolumn{1}{c}{ Aspek Penilaian } & \multicolumn{1}{c}{ Indikator } \\
\hline \multirow{3}{*}{ Teori Pembelajaran } & 1. mengandung unsur konstruktivisme \\
& 2. dapat digunakan untuk aktivitas inkuiri (saintifik) \\
& 3. gejala sains bersifat kontekstual \\
\hline \multirow{3}{*}{ Hasil Belajar } & 1. menghasilkan pengetahuan sains \\
& 2. melatih keterampilan proses sains \\
& 3. mengembangkan sikap saintifik \\
\hline 1. komponen kit dapat disepadukan \\
2. kecukupan bagi eksperimen \\
3. efisien digunakan \\
4. tidak berbahaya \\
5. komponen kit tahan benturan \\
6. kotak tertutup rapat \\
7. menarik perhatian \\
\hline 1. mudah disiapkan dan dikemas \\
2. mudah digunakan siswa \\
3. mudah dibawa-bawa siswa \\
\end{tabular}


Sementara itu, uji praktikalitas penggunaan kit THE dilakukan setelah kit dinyatakan valid. Pengujian praktikalitas ini dilakukan dengan meminta tanggapan siswa setelah menggunakan kit dalam proses pembelajaran di sekolah. Instrumen yang digunakan adalah angket pendapat siswa terhadap kemudahan penggunaan kit dalam eksperimen. Dalam penelitian ini uji praktikalitas telah dilakukan terhadap 20 siswa di salah satu SMP kota Pekanbaru yang dipilih secara acak dari 60 siswa kelas VIII. Indikator penilaian kebolehgunaaan atau kepraktisan penggunaan kit THE ditunjukkan oleh Tabel 2.

Tabel 2 Indikator penilaian kepraktisan Kit THE menurut siswa

\begin{tabular}{cl}
\hline No & \multicolumn{2}{c}{ Indikator } \\
\hline 1 & $\begin{array}{l}\text { Kemudahan dalam menyiapkan dan } \\
\text { mengemas kembali peralatan dan } \\
\text { bahan dalam kit THE }\end{array}$ \\
2 & $\begin{array}{l}\text { Kemudahan dalam memahami } \\
\text { kegunaan semua alat dan bahan } \\
\text { dalam kit THE }\end{array}$ \\
3 & $\begin{array}{l}\text { Kemudahan dalam menggunakan } \\
\text { berbagai peralatan dan bahan dalam } \\
\text { kit THE dalam melakukan } \\
\text { Kemudahan dan dan } \\
\text { observasi dan melakukan pengukuran } \\
\text { feno mena cahaya dan optik } \\
\text { Kemudahan dalam membawa kit } \\
\text { dalam tas sekolah }\end{array}$ \\
\hline
\end{tabular}

Tabel 2 menunjukkan bahwa penilaian siswa terhadap kemudahan penggunaan kit meliputi 5 indikator. Indikator tersebut diantaranya adalah kemudahan dalam penyiapan dan pengemasan, kemudahan dalam memahami, kemudahan dalam penggunaan, kemudahan dalam pengamatan dan pengukuran, dan kemudahan dalam membawa kit.

\section{Hasil dan Pembahasan}

Hasil penelitian pengembangan ini adalah produk berupa kit eksperimen untuk topik cahaya dan optik bagi siswa SLTP yang dapat digunakan oleh siswa untuk melakukan eksperimen di rumah. Proses pengembangan kit THE ini telah mengikuti langkahlangkah model ADDIE.

Kit THE cahaya dan optik yang dikembangkan terdiri dari beberapa alat dan bahan yang disusun sedemikian rupa dalam sebuah kotak transparan dan berukuran kecil sehingga kit mudah dibawa siswa di dalam tas sekolah mereka. Alat dan bahan yang tersusun di dalam kit THE cahaya dan optik ini adalah alat dan bahan yang diperlukan untuk hampir seluruh eksperimen cahaya dan optik SLTP. Sebahagian besar alat dirancang dan dibuat sesuai dengan keperluan penelitian, yaitu berukuran relatif kecil, terbuat dari bahan yang tidak mudah pecah, tidak berbahaya, dan relatif berharga murah. Sebahagian alat dan bahan lainnya dibeli dengan kriteria: murah dan mudah didapat di pasaran.

Hasil penilaian pakar terhadap kit yang telah dirakit menunjukkan bahwa semua pakar memberikan penilaian setuju dan sangat setuju untuk semua aspek yang dinilai. Semua pakar menyatakan sangat setuju bahwa kit THE tidak berbahaya, dua dari tiga pakar menyatakan sangat setuju bahwa kit THE tidak mudah pecah, dapat digunakan berulang-ulang, dan mudah dikemas dan dibawa. Penilaian pakar ini menunjukkan bahwa secara umum kit THE cahaya dan optik dipandang layak untuk digunakan oleh siswa SLTP dalam melaksanakan eksperimen di rumah.

Penilaian kemudahan penggunaan kit THE (praktikalitas) oleh 20 siswa SMP sebagai partisipan dalam penelitian ini menunjukkan sebahagian besar siswa berpendapat bahwa kit sangat mudah mereka bawa ke mana saja. Ukuran kotak/kit yang relatif kecil dengan bobot yang relatif ringan membuat kit mudah dimasukkan siswa ke dalam tas sekolahnya untuk dibawa pulang dan dibawa kembali ke sekolah.

Pada aspek kemudahan dalam mengemas komponen alat di dalam kit, hanya ada dua siswa yang merasa kesulitan menyusun atau mengemas alat dan bahan dalam kotak/ kit, sedangkan sebahagian besar siswa berpendapat bahwa alat mudah dikemas atau disusun di dalam kotak kit. Kotak/kit terbuat dari bahan plastik transparan, dan posisi alat dan bahan telah ditetapkan 
sedemikian rupa, sehingga siswa dapat melihat posisi itu dari luar kotak.

Salah satu tujuan penting kit THE adalah dapat digunakan dalam eksperimen di rumah. Hampir semua siswa menyatakan bahwa mereka dapat dengan mudah menggunakan alat dan bahan dalam kit THE untuk melakukan eksperimen di rumah. Meskipun demikian, terdapat $20 \%$ siswa yang masih merasa kesulitan menggunakan kit tersebut. Kesulitan ini dapat disebabkan oleh instruksi penggunaan kit dalam LKS atau penjelasan guru kurang optimal, atau dapat pula disebab kan karena adanya siswa yang tidak menyenangi eksperimen.

Semua siswa menyatakan bahwa mereka dapat melakukan eksperimen kapan saja dan di mana saja di luar sekolah. Hal ini disebabkan karena kit THE dirancang sedemikian rupa sehingga tidak memerlukan tempat khusus seperti laboratorium untuk melakukan ekspe rimen, atau alat dan bahan pendukung lainnya seperti: sumber energi listrik, pencahayaan khusus, atau meja praktikum.

Terdapat 20\% siswa yang menyatakan bahwa sebagian alat tidak dapat menunjukkan fungsinya dalam eksperimen yang mereka jalankan. Hal ini disebabkan siswa tersebut kurang memperhatikan penjelasan guru dan ada perasaan takut menggunakan peralatan. Sementara itu, $80 \%$ siswa lainnya menyatakan bahwa alat berfungsi dengan baik. Semua siswa menyatakan setuju dan sangat setuju bahwa eksperimen mereka dapat mereka ulangi. Karena alat mudah dikemas dan tidak memerlukan tempat khusus dan alat pendukung lainnya dalam penggunaannya, membuat siswa merasa mudah untuk mengulang eksperimen mereka.

Terdapat $25 \%$ siswa yang mengaku bahwa mereka kesulitan bekerja sendiri dalam melaksanakan eksperimen mereka. Sedangkan 75 lainnya menyatakan bahwa mereka dapat melaksanakan sendiri eksperimen mereka. Siswa yang merasa kesulitan disebabkan kurang memperhatikan penjelasan guru, kurang cermat membaca LKS, merasa takut menggunakan alat-alat eksperimen, dan belum terbiasa melaksanakan eksperimen khususnya eksperimen secara mandiri di rumah.

Berdasarkan hasil penilaian kemudahan penggunaan kit THE oleh siswa yang diuraikan di atas, secara umum dapat disimpulkan bahwa sebagian besar siswa dapat dengan mudah menggunakan kit THE cahaya dan optik. Hanya sebagian kecil siswa yang merasa kesulitan menggunakan kit THE ini. Kesulitan ini lebih disebabkan oleh siswa kurang terbiasa dengan eksperimen sehingga tidak percaya diri, dan kurang memperhatikan instruksi eksperimen baik oleh guru maupun oleh petunjuk dalam LKS dan bukan disebabkan oleh desain dan konstruksi kit THE itu sendiri.

\section{Kesimpulan}

Untuk meningkatkan keterampilan saintifik siswa, mereka haruslah melaksana kan berbagai kegiatan sains secara langsung. Keterbatasan peralatan, dan waktu menjalankan eksperimen sains di sekolah akan diatasi dengan mengembangkan perangkat eksperimen yang dapat dibawa pulang oleh siswa. Kit take home experiments untuk topik cahaya dan optik dalam kajian ini telah didisain sedemikian rupa sehingga dapat digunakan dengan mudah oleh siswa di rumah. Kit THE ini juga dipandang layak oleh pakar sebagai media pembelajaran sains khususnya untuk memahami konsep dan aplikasi cahaya dan optik siswa SLTP.

Dengan menggunakan kit THE ini, para siswa dapat melatih kemampuan saintifik mereka di sekolah dibawah bimbingan guru dan di rumah dapat menjalankan eksperimen secara mandiri atau dibantu oleh orang tua. Pengalaman langsung ini memberikan manfaat yang besar bagi siswa dalam mengembangkan kemampuan dan sikap saintifik mereka. Hasil kajian Ergul (2011) mendapatkan bahwa pengalaman langsung (hands-on activity) siswa dalam pengajaran berbasis pendekatan inkuiri akan meningkat kan sikap saintifik dan keterampilan proses sains serta memberikan kontribusi positif terhadap prestasi akademik sains, literasi sains, dan sikap terhadap sains. Sementara itu, Trumper (2002) mengatakan bahwa pembelajaran sains tak mungkin dilakukan tanpa kerja praktikum atau kerja lapangan. 


\section{Daftar Pustaka}

Bilgin, Ibrahim, 2006. The Effect of hands-on activities incorporating cooperative learning approach on eight students' science process skills and attitudes toward science. Journal of Baltic Science Education, 1(9); 27-37.

Ergul, Remziye.,et.al., 2011. The effect of inquiry-based science teaching on elementary school students' science process skill and science attitudes. Bulgarian. Journal of Science and Education Policy (BJSEP), 5(1), 48-68.

Gendjova, Aleksandriya, 2007. Enhancing students' interest in Chemistry by home experiment. Journal of Baltic Science Education. 6(3).

Hazrulrizawati bt. Abd. Hamid, 2007. Perbandingan Tahap Penguasaan Kemahiran Proses Sains Dan Cara Penglibatan Pelajar Dalam Kaedah Amali Tradisional Dengan Kaedah Makmal Mikro Komputer. Desertasi, Universiti Teknologi Malaysia.

Kaur, Ms. Gurpreet, 2013. Scientific in relation to critical thinking among teachers. Educationia Confab, 2 (8), 24-29.

Kemdikbud, 2013. Materi Pelatihan Kurikulum 2013. Kementerian Pendidikan Nasional, Jakarta.

Magliaro, S.G. \& Shambaugh, N., 2006. Student's model of instructional design. ETR\&D, 54(1), 83-106.

McGurr, M., 2008. Improving the flow of material in a catalogingdepartment: Using ADDIE for a project in Ohio State University Libraries. Library Resources \& Technical Service, 52(2), 54-60.

Mallya, Aarti., Mensah, Felicia Moore., Contento, Isobel R., Koch, Pamela A., and Barton Angela Calabrese, 2012. Extending science beyond the classroom door: learning from students' expe riences with the choice, control and change (C3) curriculum. Journal of Research in Science Teaching, vol. 49, no. 2, pp. 244-269.

Nuryani Rustaman, 2013. http://file.upi. edu/direktori/sps/prodi.pendidikan_ipa/ 195012311979032-nuryani_rustaman/ asesmen pendidikan ipa.pdf last update 13 oktober 2013 .

Norlander-Case, K., et.al., 1998. The role of collaborative inquiry and reflective practice in teacher preparation. The Professional Educator. 21(1); 1-14.

Ottander, Christina dan Grelsson, Gunnel, 2006. Laboratory work: the teacher perspective. Journal of Biological Education, 40(3), pp.113-118.

Sudarwan, 2013. Pendekatan-pendekatan Ilmiah dalam Pembelajaran. Pusbang prodik.

Sumintono, Bambang. Ibrahim, M. Ali, \& Phang, Fatin Aliah, 2010. Pengajaran Sains dengan Praktikum Laboratorium: Perspektif dari Guru-Guru Sains SMPN di Kota Cimahi. Jurnal Pengajaran MIPA, 15(2); 120-127.

Suyana, Iyon, 2011. Kemampuan dalam mendeskripsikan hubungan antar konsep fisika siswa SMP dalam pembelajaran berbasis free inquiry dalam upaya meningkatkan kemampuan generik sains. Jurnal Pengajaran MIPA, 16(1); 37-44.

Trumper, Ricardo, 2002. What do we expect from students' physics laboratory experiments?. Journal of Science Education and Technology, 11(3), pp.221-227.

Yennita, Mugi Sukmawati, Zulirfan, 2012. Hambatan pelaksanaan praktikum IPA fisika yang dihadapi guru SMP Negeri di kota Pekanbaru. Jurnal Pendidikan, $3(1), 1-8$.

Zulirfan., Subahan Mohd. Meerah., Zanaton Hj. Ikhsan, 2013. Early study in developing take-home physics experiment: an alternative strategy to improve science process skills and scientific attitudes. Prosiding Seminar Serantau UKM-Unri. 